Article

\title{
Tumor Size-Dependent Anticancer Efficacy of Chlorin Derivatives for Photodynamic Therapy
}

\author{
Ji-Eun Chang ${ }^{1,+(\mathbb{D})}$, Yang Liu ${ }^{2,+}$, Tae Heon Lee ${ }^{2}$, Woo Kyoung Lee ${ }^{2}$, Il Yoon ${ }^{2, *}$ \\ and Kwhanmien Kim 1,3,* \\ 1 Department of Thoracic and Cardiovascular Surgery, Seoul National University Bundang Hospital, \\ Seongnam-si, Gyeonggi-do 13620, Korea; iris0515@hanmail.net \\ 2 Nano Manufacturing Institute, School of Nanoscience and Engineering, Inje University, Gimhae 50834, \\ Korea; gavin881027@163.com (Y.L.); taehun5651@naver.com (T.H.L.); wlee@inje.ac.kr (W.K.L.) \\ 3 Department of Thoracic and Cardiovascular Surgery, Seoul National University College of Medicine, \\ Seoul 03080, Korea \\ * Correspondence: yoonil71@inje.ac.kr (I.Y.); kmkim0070@snubh.org (K.K.); \\ Tel.: +82-55-320-3871 (I.Y.); +82-31-787-7131 (K.K.); Fax: +82-55-321-7034 (I.Y.); +82-31-787-4050 (K.K.) \\ + These authors contributed equally to this work.
}

Received: 2 May 2018; Accepted: 26 May 2018; Published: 29 May 2018

\begin{abstract}
Photodynamic therapy (PDT) with a suitable photosensitizer molecule is a promising anticancer treatment. We evaluated two chlorin molecules as potential photosensitizers, methyl pyropheophorbide a (MPPa) and N-methoxyl purpurinimide (NMPi), against A549 human lung adenocarcinoma cells in vitro as well as in A549 tumor-bearing mice in vivo. Cell viability, microscopy, and fluorescence-activated cell sorting (FACS) analyses were performed for the in vitro studies. MPPa and NMPi showed high phototoxicity in vitro, which was dependent on the concentration of the photosensitizers as well as the light irradiation time. In the animal study, tumor volume change, tumor surface alterations, and hematoxylin \& eosin (H\&E) and terminal deoxyribonucleotidyl transferse-mediated dUTP nick-end labelling (TUNEL) staining analyses were performed and compared between small (tumor volume of $<50 \mathrm{~mm}^{3}$ ) and large (tumor volume of $>50 \mathrm{~mm}^{3}$ ) size of initial tumors. MPPa and NMPi showed high anticancer efficacy against small-size tumors, indicating that early treatment with PDT is effective. Especially, repeated two times PDT with NMPi allowed almost complete eradication against small-size tumors. However, MPPa and NMPi were not effective against large-size tumors. In conclusion, the two chlorin derivatives, MPPa and NMPi, show good anticancer efficacy as promising photosensitizers for PDT in vitro and in vivo. Moreover, their activity in vivo was significantly dependent on the initial tumor size in mice, which confirms the importance of early cancer treatment.
\end{abstract}

Keywords: cancer treatment; chlorin; photodynamic therapy (PDT); photosensitizer; tumor size

\section{Introduction}

Cancer is one of the most common diseases in the world [1]. Complete tumor eradication is the ultimate goal to achieve perfect healing without recurrence, and recurrence after cancer therapy results in low survival rate as shown in cancer clinical use [2].

Photodynamic therapy (PDT) is a non-invasive and patient-specific cancer therapy using photosensitizers, light, and molecular oxygen in the tumor site for various cancers, such as cervical, endobronchial, esophageal, brain, gastric, and lung cancers [3-7]. PDT possesses several advantages, in that it is tumor selective, minimally invasive, repeatable, and a non-surgical alternative [8-10]. The action mechanism of PDT has been introduced elsewhere [5,7]. Upon administration, the 
photosensitizer molecule selectively accumulates within the tumor tissues. When the photosensitizer is exposed to a specific wavelength of light, it becomes activated from a ground state to an excited state, and, while returning to the ground state, it releases energy that is transferred to oxygen in the body to generate reactive oxygen species (ROS, e.g., singlet oxygen, ${ }^{1} \mathrm{O}_{2}$ ), which induces cellular toxicity to damage cancer cells $[11,12]$.

Chlorins of the porphyrin family are promising second-generation photosensitizer molecules for PDT with a high extinction coefficient at an appropriate wavelength and good ROS photogeneration capabilities [13-15]. In addition, chlorins are abundantly available from natural sources such as plants (chlorophyll paste) and algae (Spirulina maxima) [16], and can be synthesized in a straightforward manner into chlorin derivatives with various active functional groups on the chlorin moiety [17]. Recently, our group synthesized several chlorin derivatives to evaluate structure-activity relationship [18-23]. Among the chlorin derivatives synthesized by our group, we report the activity of two chlorins as photosensitizers, methyl pyropheophorbide a (MPPa) and N-methoxyl purpurinimide (NMPi), in this present study [21].

In our previous work, we have shown efficient anticancer activity of PDT using MPPa and $\mathrm{NMPi}$, and their chlorin derivatives against HeLa cells [21], where we focused on the development of long wavelength-absorbing photosensitizers using cationic chlorins. However, $630 \mathrm{~nm}$ laser is still common for clinical uses [24-26]. Moreover, the commercially available first-generation photosensitizer, Photofrin ${ }^{\circledR}$, produces certain limits to clinical application, such as relatively poor tissue selectivity, low absorption of light, poor tissue penetration of light, skin sensitivity, and adverse effects [26]. Therefore, it is still a great challenge to develop second-generation photosensitizers with high PDT activity as well as without any adverse effects [27]. In this paper, we evaluated two chlorin derivatives, MPPa and NMPi, against A549 cells in vitro as well as in A549 tumor-bearing mice in vivo [28-32].

Furthermore, in this study, we correlated PDT activity with tumor size in mice. Although anticancer efficacy of PDT in various animal models of cancer have been reported, to the best of our knowledge, the effect of PDT according to tumor size has not yet been investigated using tumor animal models. According to clinical reports, there is a remarkable correlation between response rate after PDT and tumor size [15,33-36]. For early esophageal cancers, it was reported that when the tumor size is up to $1 \mathrm{~cm}$, PDT results in complete regression in 100\% patients. However, when the tumor size is 3.1-5.0 cm, only $33.3 \%$ of patients achieve complete regression [37]. In addition, one of the recommended criterion for the treatment of lung cancer using PDT is a tumor size less than $1 \mathrm{~cm}$ in the greatest diameter [38].

\section{Results and Discussion}

\subsection{Characterization of Prepared Photosensitizers}

All characterization data for methyl pyropheophorbide a (MPPa) and $N$-methoxyl purpurinimide (NMPi) (Figure 1) are identical with those in the literature (Figures S1-S3), and are summarized as following [21].

MPPa: ${ }^{1} \mathrm{H}$ NMR $\left(\mathrm{CDCl}_{3}\right) \delta$ : 9.17, 9.06, 8.47 (each s, each $\left.1 \mathrm{H}, 10-\mathrm{H}, 5-\mathrm{H}, 20-\mathrm{H}\right), 7.77-7.83(\mathrm{~m}, 1 \mathrm{H}$, $\left.3^{1}-\mathrm{H}\right), 6.08\left(\mathrm{~m}, 2 \mathrm{H}, 3^{2}-\mathrm{H}\right), 5.20\left(\mathrm{~d}, J=20.0 \mathrm{~Hz}, 1 \mathrm{H}, 13^{2}-\mathrm{H}\right), 5.05\left(\mathrm{~d}, J=20.0 \mathrm{~Hz}, 1 \mathrm{H}, 13^{2}-\mathrm{H}\right), 4.40-4.44$ $(\mathrm{m}, 1 \mathrm{H}, 18-\mathrm{H}), 4.20-4.22(\mathrm{~m}, 1 \mathrm{H}, 17-\mathrm{H}), 3.42\left(\mathrm{q}, J=7.3 \mathrm{~Hz}, 2 \mathrm{H}, 8^{1}-\mathrm{CH}_{2}\right), 3.01,3.31,3.50,3.61$ (each s, $\left.12 \mathrm{H}, \mathrm{OCH}_{3}+\mathrm{CH}_{3}\right), 2.51-2.53\left(\mathrm{~m}, 2 \mathrm{H}, 17^{2}-\mathrm{CH}_{2}\right), 2.21-2.27\left(\mathrm{~m}, 2 \mathrm{H} 17^{1}-\mathrm{CH}_{2}\right), 1.80(\mathrm{~d}, J=7.4 \mathrm{~Hz}, 3 \mathrm{H}$, $\left.18^{1}-\mathrm{CH}_{3}\right), 1.56\left(\mathrm{t}, J=7.5 \mathrm{~Hz}, 3 \mathrm{H}, 8^{2}-\mathrm{CH}_{3}\right), 0.75(\mathrm{br}, 1 \mathrm{H}, \mathrm{NH}),-1.92(\mathrm{br}, 1 \mathrm{H}, \mathrm{NH})$; UV-Vis $(\mathrm{nm})(\log \varepsilon)$ : 412.90 (1.54), 509.90 (1.07), 539.80 (1.01), 610.70 (0.93), 667.90 (1.49); Anal. calcd for $\mathrm{C}_{34} \mathrm{H}_{36} \mathrm{~N}_{4} \mathrm{O}_{3} \mathrm{C}$ 74.43; H 6.61; N 10.21. Found C 74.38, H 7.14, N 10.06.

NMPi: ${ }^{1} \mathrm{H}$ NMR $\left(\mathrm{CDCl}_{3}\right) \delta: 8.53,9.33,9.58$ (each s, each $\left.1 \mathrm{H}, 10-\mathrm{H}, 5-\mathrm{H}, 20-\mathrm{H}\right), 7.86(\mathrm{dd}, J=17.8 \mathrm{~Hz}$, $\left.11.6 \mathrm{~Hz}, 1 \mathrm{H}, 3^{1}-\mathrm{H}\right), 6.29\left(\mathrm{~d}, J=17.8 \mathrm{~Hz}, 1 \mathrm{H}, 3^{2}-\mathrm{H}\right), 6.17\left(\mathrm{~d}, J=11.6 \mathrm{~Hz}, 1 \mathrm{H}, 3^{2}-\mathrm{H}\right), 5.28(\mathrm{~d}, J=9.7 \mathrm{~Hz}$, $1 \mathrm{H}, 17-\mathrm{H}), 4.35(\mathrm{q}, J=7.4 \mathrm{~Hz}, 1 \mathrm{H}, 18-\mathrm{H}), 4.39\left(\mathrm{~s}, 3 \mathrm{H}, \mathrm{NOCH}_{3}\right), 3.16,3.33,3.58,3.67$ (each s, each $\left.3 \mathrm{H}, \mathrm{OCH}_{3}+\mathrm{CH}_{3}\right), 3.67\left(\mathrm{q}, J=7.6 \mathrm{~Hz}, 2 \mathrm{H}, 8^{1}-\mathrm{CH}_{2}\right), 1.90-2.08,2.40-2.56,2.73-2.85$ (each $\mathrm{m}, 4 \mathrm{H}$, 
$\left.17^{1}+17^{2}-\mathrm{CH}_{2}\right), 1.72\left(\mathrm{~d}, J=7.3 \mathrm{~Hz}, 3 \mathrm{H}, 18^{1}-\mathrm{CH}_{3}\right), 1.63\left(\mathrm{t}, J=7.6 \mathrm{~Hz}, 3 \mathrm{H}, 8^{2}-\mathrm{CH}_{3}\right), 0.14,0.23$ (each br s, each 1H, $2 \times \mathrm{NH})$; UV-Vis: $(\mathrm{nm})(\log \varepsilon): 410.00$ (1.51), 481.10 (0.84), 551.50 (1.28), 707.10 (1.47); Anal. calcd for $\mathrm{C}_{35} \mathrm{H}_{37} \mathrm{~N}_{5} \mathrm{O}_{5}\left(\mathrm{CH}_{3} \mathrm{OH}\right) \mathrm{C} 67.59 ; \mathrm{H} 6.46 ; \mathrm{N}$ 10.95. Found C 67.95, H 6.98, N 10.95.
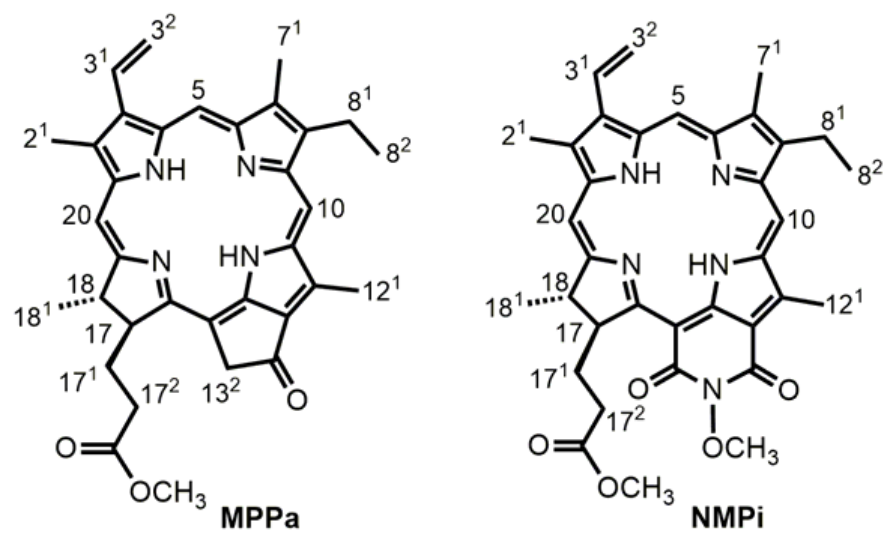

Figure 1. Chemical structures with numbering for methyl pyropheophorbide a (MPPa) and N-methoxyl purpurinimide (NMPi).

\subsection{In Vitro Phototoxicity}

The photoactivity and dark toxicity of MPPa and NMPi were evaluated against A549 cells by MTT assay at various concentrations $(1-20 \mu \mathrm{M})$ after 3 and $24 \mathrm{~h}$ incubation times (Tables S1 and S2). For the photoactivity study, A549 cells were irradiated to give total light dose of $2 \mathrm{~J} / \mathrm{cm}^{2}$ for $15 \mathrm{~min}$, which is the same experimental condition as our previous cell viability study [21].

We compared photoactivities of MPPa and NMPi against A549 and HeLa cells. Figure 2 exhibited negligible dark toxicity until $20 \mu \mathrm{M}$, while upon photoirradiation, the cell viability decreased for MPPa and NMPi consistent with the increase in their concentrations as well as incubation time. Photoactivity of $\mathrm{IC}_{50}$ values of MPPa and NMPi against A549 and HeLa cells are summarized in Table 1. MPPa showed higher photoactivity than NMPi against both A549 and HeLa cells. It is interesting that MPPa presented higher photoactivity against HeLa cells than A549 cells, while NMPi had higher photoactivity against A549 cells than HeLa cells. This may be because the two cell lines have different morphology, histology, and biochemistry based on differences in phenotypic and genotypic characteristics and origins determining resistance and biological response $[29,30]$.

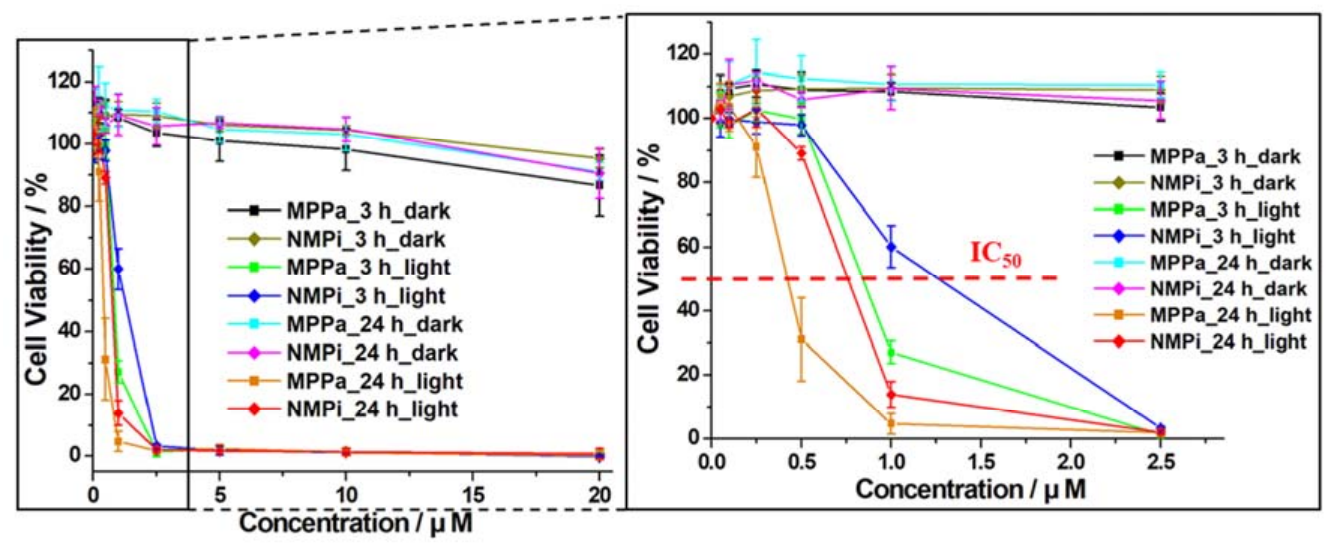

Figure 2. In vitro phototoxicity (total light dose $2 \mathrm{~J} / \mathrm{cm}^{2}$ for $15 \mathrm{~min}$ ) and dark toxicity against A549 cells by 3-(4,5-Dimethylthiazol-2-yl)-2,5-diphenyltetrazolium bromide) (MTT) assay after 3 and $24 \mathrm{~h}$ incubation times at various concentrations (1-20 $\mu \mathrm{M})$ of MPPa and NMPi (left), and expanded figure for low concentrations (right). Error bars represent the SD of three replicate experiments. Red dashed line at $50 \%$ cell viability presents $\mathrm{IC}_{50}$ value (half maximal inhibitory concentration). 
Table 1. $\mathrm{IC}_{50}$ values of MPPa and NMPi against A549 ${ }^{\mathrm{a}}$ and $\mathrm{HeLa}{ }^{\mathrm{b}}$ cells at $3 \mathrm{~h}$ and $24 \mathrm{~h}$, and $12 \mathrm{~h}$ incubation times after irradiation (total light dose $2 \mathrm{~J} / \mathrm{cm}^{2}$ for $15 \mathrm{~min}$ ), respectively.

\begin{tabular}{cccc}
\hline Cell Line (Assay) & Incubation Time (h) & MPPa $(\mu \mathbf{M})$ & NMPi $(\mu \mathbf{M})$ \\
\hline $\mathrm{A}^{2} 49^{\mathrm{a}}$ (MTT) & 3 & 0.89 & 1.15 \\
& 24 & 0.44 & 0.73 \\
\hline $\mathrm{HeLa}^{\mathrm{b}}$ (WST-8) & 12 & 0.28 & 2.71 \\
\hline
\end{tabular}

Note: ${ }^{a}$ In this work by MTT assay after $3 \mathrm{~h}$ and $24 \mathrm{~h}$ incubation times; and ${ }^{\mathrm{b}}$ Reference [21] by WST-8 assay at $12 \mathrm{~h}$ incubation time.

Before starting the in vivo study, we confirmed the suitable experimental condition of the in vivo system with a $630 \mathrm{~nm}$ laser $\left(400 \mathrm{~mW} / \mathrm{cm}^{2}\right)$ as well as confirmed the drug dose of the two chlorins, MPPa and NMPi. Therefore, we reevaluated light and drug doses against A549 cells in vitro. Figure 3 shows in vitro cell viabilities against A549 cells after $4 \mathrm{~h}$ incubation time by CCK-8 with PBS (control), $\mathrm{MPPa}$, and NMPi at a concentration range of 1-10 $\mu \mathrm{M}$. Dark toxicity of NMPi was negligible until $10 \mu \mathrm{M}$. MPPa presented high dark toxicity at $5 \mu \mathrm{M}$ and $10 \mu \mathrm{M}$ concentrations, which was not consistent with that obtained by MTT assay shown in Figure 1 (negligible dark toxicity until $20 \mu \mathrm{M}$ ). In the previous study, MPPa and NMPi had no dark toxicity against HeLa cells until $10 \mu \mathrm{M}$ [21].

(a)

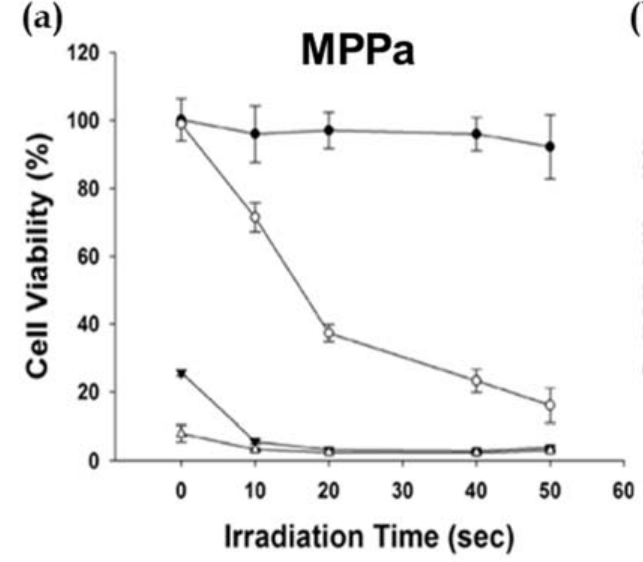

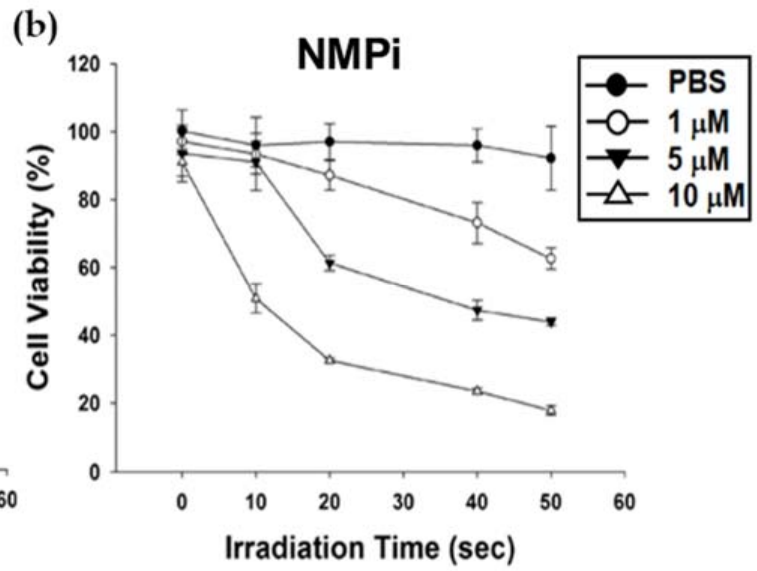

Figure 3. In vitro phototoxicity $\left(630 \mathrm{~nm}\right.$ laser, $\left.400 \mathrm{~mW} / \mathrm{cm}^{2}\right)$ and dark toxicity against A549 cells by CCK-8 at $4 \mathrm{~h}$ incubation time after treating with PBS or various concentrations $(1,5$, and $10 \mu \mathrm{M})$ of (a) MPPa or (b) NMPi followed by light irradiation for $0,10,20,40$, or $50 \mathrm{~s}\left(0,4,8,16\right.$, or $20 \mathrm{~J} / \mathrm{cm}^{2}$, respectively). Error bars represent the $\mathrm{SD}$ of three replicate experiments.

Phototoxicity of MPPa and NMPi was evaluated with the photoirradiation time set at 10-50 s $\left(4-20 \mathrm{~J} / \mathrm{cm}^{2}\right)$. Under laser treatment, photoactivity of PBS was negligible. However, MPPa and NMPi exhibited significantly high photoactivity that were dependent on their concentrations as well as the irradiation time. MPPa showed better phototoxicity compared with NMPi. Furthermore, MPPa and NMPi showed better photoactivity than chlorin e6-loaded chitosan nanoparticles reported by Wang et al. [31].

The results of in vitro cell viability studies (Figures 2 and 3) clearly suggest that effective intracellular uptake of MPPa and NMPi by A549 cells follows photodynamic activity to induce apoptosis in tumor cells.

Microscopic analysis (Figure 4) was performed to visualize apoptotic cell death caused by PDT against A549 cells by annexin V-FITC staining after treating with PBS or various concentrations $(1-10 \mu \mathrm{M})$ of NMPi followed by light irradiation for 0 or $8 \mathrm{~J} / \mathrm{cm}^{2}$. Nuclei and apoptotic cells were stained with DAPI (blue color, first column) and annexin V-FITC (green color, second column). PDT with NMPi along with irradiation of $8 \mathrm{~J} / \mathrm{cm}^{2}$ revealed increased effect of PDT corresponding to 
concentration, which was consistent with the results of in vitro phototoxicity in Figures 1 and 2 . However, PBS and PS only without PDT showed no apoptotic cells, except at $10 \mu \mathrm{M}$ NMPi concentration, which exhibited some apoptotic cells due to the low dark toxicity.

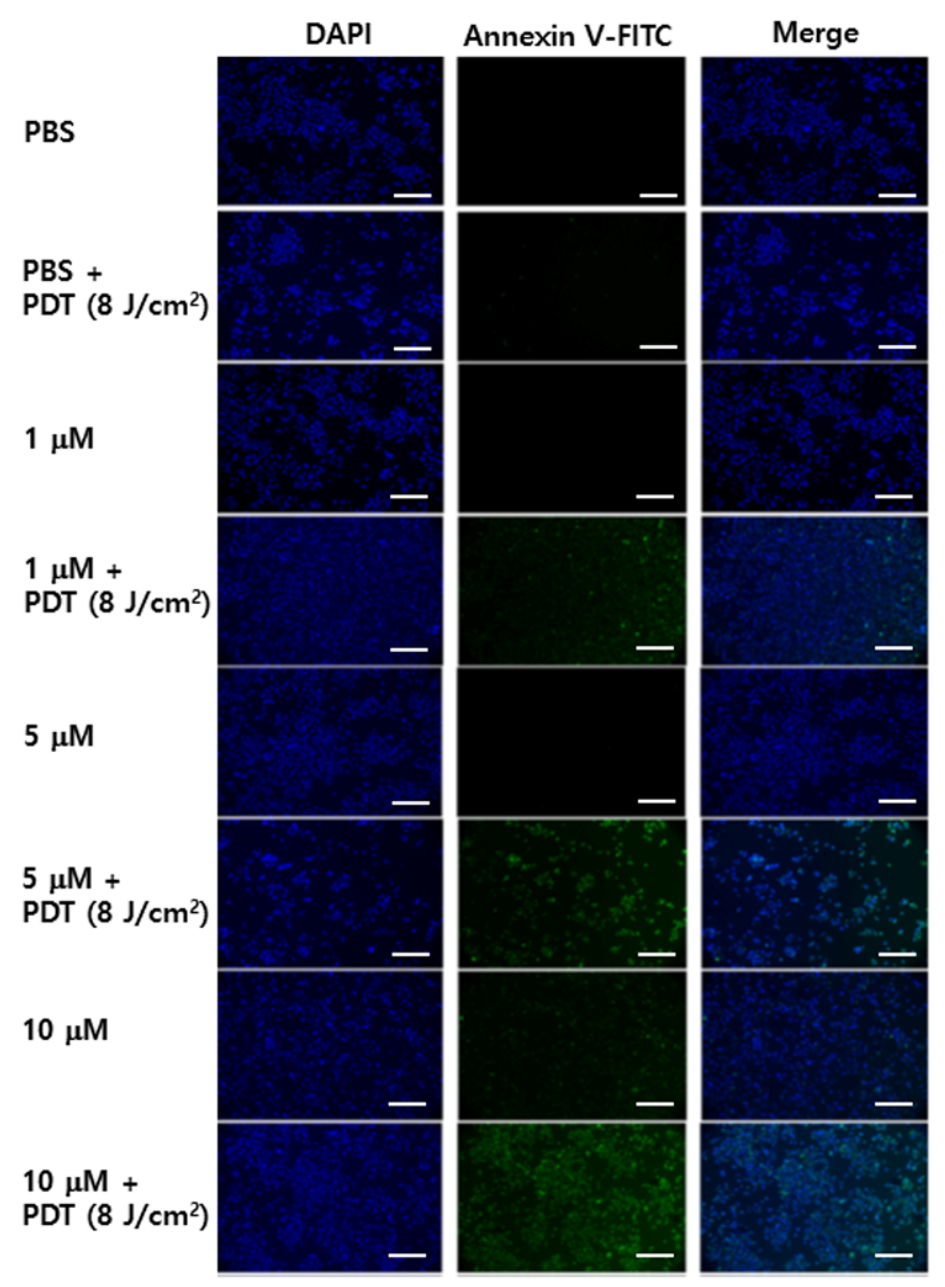

Figure 4. Microscopic analysis of apoptotic A549 cells by annexin V-FITC staining after treating PBS or various concentrations (1-10 $\mu \mathrm{M})$ of NMPi followed by light irradiation for 0 or $8 \mathrm{~J} / \mathrm{cm}^{2}$. DAPI stain (blue, first column) and annexin V-FITC stain (green, second column) indicate nuclei and apoptotic cells, respectively. Bars, $100 \mu \mathrm{m}$.

We tested photostability (photobleaching) of MPPa and NMPi in DMSO $(4 \mu \mathrm{M})$ with light irradiation up to $20 \mathrm{~min}$ (total light energy $2.7 \mathrm{~J} / \mathrm{cm}^{2}$ ) as shown in Figure 5 a (Figures S3 and S4) [12]. MPPa (92.2\%) showed better photostability than NMPi (82.7\%), which may be why MPPa has better photoactivity than NMPi.

To quantify the relative photoactivity of MPPa and NMPi in the absence of tumor cells, ${ }^{1} \mathrm{O}_{2}$ photogeneration was measured by 1,3-diphenylisobenzofuran (DPBF) as a selective ${ }^{1} \mathrm{O}_{2}$ acceptor (Figure 5b). NMPi presented slightly better ${ }^{1} \mathrm{O}_{2}$ photogeneration than MPPa, and NMPi was almost comparable to methylene blue (MB) as a standard ${ }^{1} \mathrm{O}_{2}$ sensitizer [39]. This result was consistent with the cell viability results shown in Figures 2 and 3.

To calculate quantitative cell death by either apoptosis or necrosis, fluorescence-activated cell sorting (FACS) analysis was performed (Figure 6) against A549 cells by double staining with annexin V-FITC and PI. Positive staining by annexin V-FITC indicates early apoptosis. Both staining by annexin V-FITC and PI show late apoptosis. Positive staining by PI indicates necrosis. Total amount of apoptotic cells (sum of early and late apoptosis) increased with an increase in irradiation energy 
from 4 to $20 \mathrm{~J} / \mathrm{cm}^{2}$ PDT $(45.19 \%, 66.49 \%, 71.71 \%$, and $72.72 \%)$, which was consistent with the in vitro phototoxicity results in Figures 1 and 2 as well as the microscopic analysis in Figure 4.
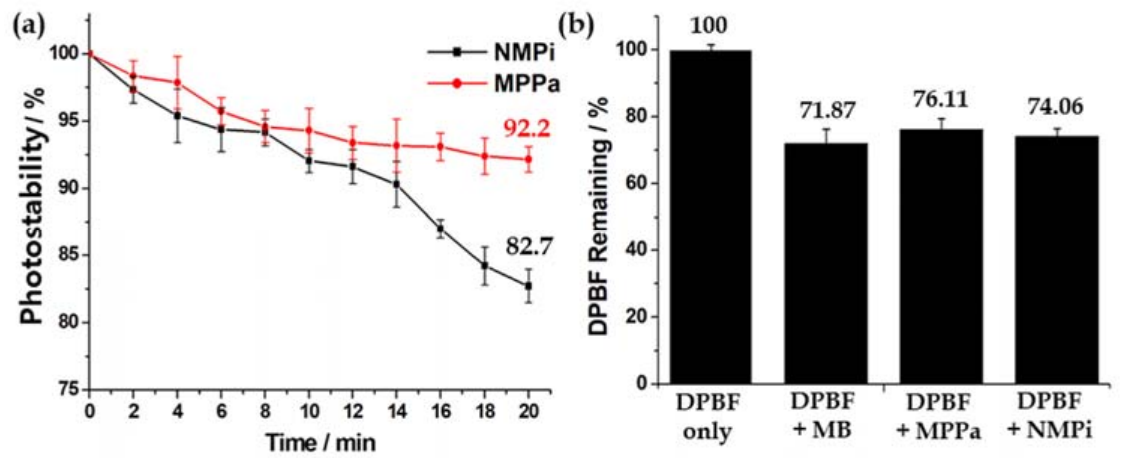

Figure 5. (a) Photostability (photobleaching) of MPPa and NMPi in DMSO $(4 \mu \mathrm{M})$ with light irradiation up to $20 \mathrm{~min}$ (total light energy $2.7 \mathrm{~J} / \mathrm{cm}^{2}$ ), measured by UV-Vis absorption. (b) 1,3-Diphenylisobenzofuran (DPBF) (50 $\mathrm{MM}$ in DMSO) remaining (\%) at $418 \mathrm{~nm}$ after photoirradiation (total light dose $2 \mathrm{~J} / \mathrm{cm}^{2}$ for $15 \mathrm{~min}$ ) in the absence (control, DPBF only) and presence of $1 \mu \mathrm{M} \mathrm{MB}$, MPPa, and NMPi. Error bars represent the SD of three replicate experiments.

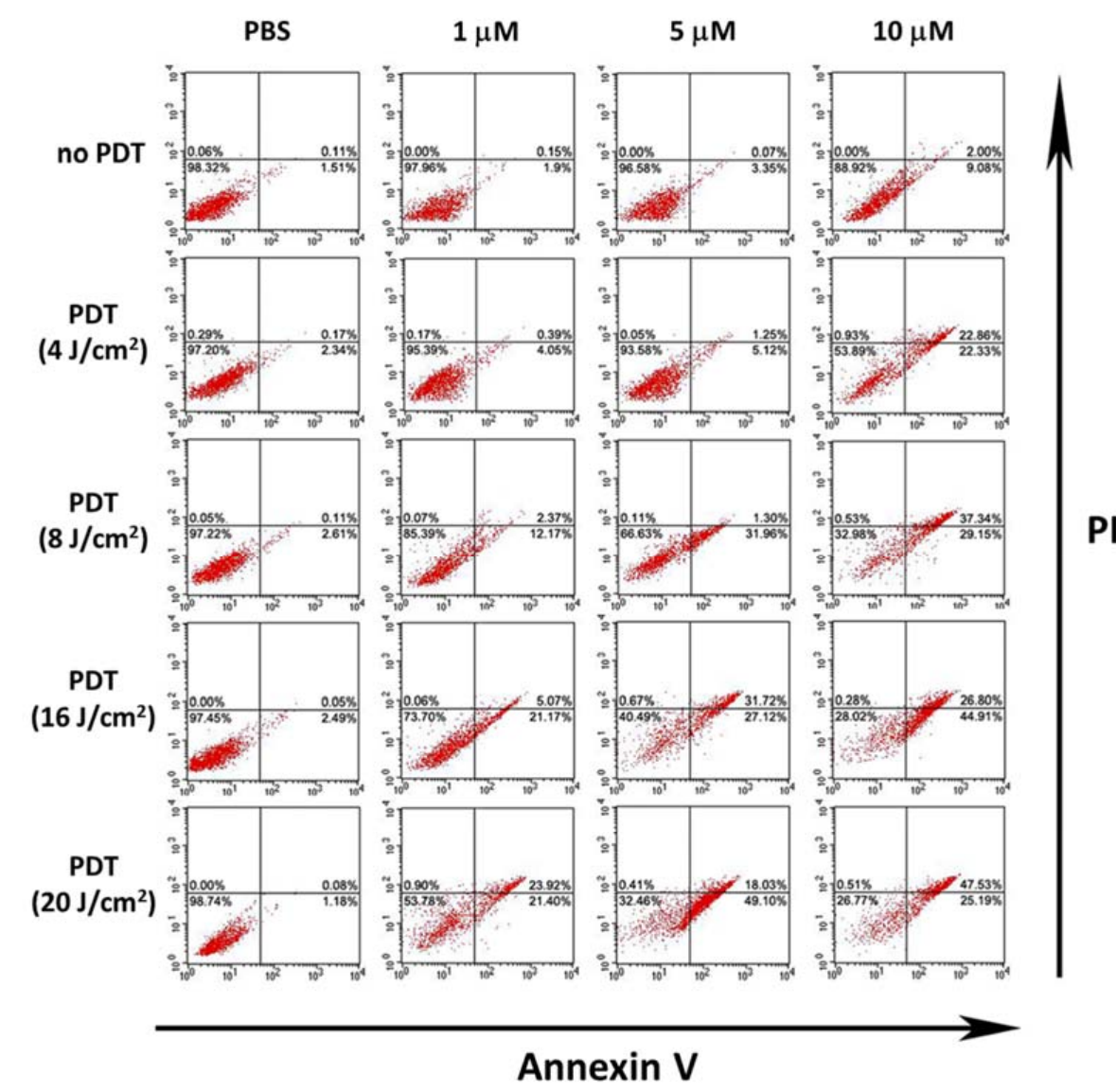

Figure 6. FACS analysis of A549 cells after treating with PBS or various concentrations $(1,5$, and $10 \mu \mathrm{M})$ of NMPi followed by light irradiation at $0,4,8,16$, or $20 \mathrm{~J} / \mathrm{cm}^{2}$. The cells were categorized as follows: both annexin V-FITC and PI negative cells, undamaged; annexin V-FITC positive and PI negative cells, early apoptotic; both annexin V-FITC and PI positive cells, late apoptotic; and annexin V-FITC negative and PI positive cells, either late apoptotic or necrotic. 


\subsection{In Vivo Photodynamic Therapeutic Efficacy}

In the in vitro result, CCK-8 assay showed some dark toxicity in MPPa (Figure 3), however, MTT assay revealed there was almost no dark toxicity for both compounds, MPPa and NMPi until $20 \mu \mathrm{M}$ concentration (Figure 2). PBS was used as a representative control group, because the drug only or light alone may give negligible activity result in the animal study due to no PDT action like in PBS alone (absence of the drug and light). We used $630 \mathrm{~nm}$ laser with output power of $400 \mathrm{~mW} / \mathrm{cm}^{2}$, which was the same experimental condition as that in our previous study; this condition allowed suitable irradiation with enough power to afford phototoxicity but no damage to cells or tissues by itself without photosensitizer administration. During the animal study, there were no side effects, which indicates that the drug alone or light alone could not make any activity results as well as the in vivo experimental conditions made no damage except the PDT action (the absence of another controls).

Therapeutic efficiency of the two photosensitizers, MPPa and NMPi, in A549 tumor-bearing mice was evaluated. Double drug injections were performed on Days 0 and 2, followed by laser irradiations $\left(200 \mathrm{~J} / \mathrm{cm}^{2}\right)$ one day after each injection on Days 1 and 3. In vivo tumor volume in A549 tumor-bearing mice (small-tumor groups $\left(<50 \mathrm{~mm}^{3}\right)$ and large-tumor groups $\left(>50 \mathrm{~mm}^{3}\right)$ ) were measured and compared based on different photosensitizers and tumor sizes.

Data are presented as means $\pm \mathrm{SD}(n=5)$ in Figure 7 . As expected, therapeutic effect was higher in the order of: $\operatorname{NMPi}\left(<50 \mathrm{~mm}^{3}\right)>\operatorname{MPPa}\left(<50 \mathrm{~mm}^{3}\right)>\operatorname{NMPi}\left(>50 \mathrm{~mm}^{3}\right)>\operatorname{MPPa}\left(>50 \mathrm{~mm}^{3}\right)$. It is noted that $\mathrm{NMPi}\left(<50 \mathrm{~mm}^{3}\right)$ caused almost complete tumor eradication, and $\mathrm{MPPa}\left(<50 \mathrm{~mm}^{3}\right)$ significantly reduced tumor volume under PDT. This result showed that under in vivo conditions, NMPi and MPPa subgroups showed so much higher therapeutic effect and a significantly lower tumor volume than control (PBS) in A549 tumor-bearing mice in both small- $(p<0.001$, one-way ANOVA) and large-size $(p<0.05$, one-way ANOVA) tumor groups. This result confirms the importance of PDT effect with suitable photosensitizer as promising anticancer treatment. However, therapeutic effects of MPPa and NMPi on mice with large-tumors $\left(>50 \mathrm{~mm}^{3}\right)$ were not high. These results indicate that initial tumor size strongly affects therapeutic effect under PDT $[15,33]$.

Interestingly, NMPi showed better PDT anticancer efficacy than MPPa in vivo (Figure 7). However, there is no significant ( $p>0.05$, one-way ANOVA) difference between NMPi and MPPa subgroups in both small- and large-size tumor groups. The increase in apoptotic cells induced by the photodynamic action supports that the anticancer effect of PDT strongly depends on the concentration of NMPi (Figures 2 and 3) and the total energy of light irradiation (Figures 4 and 6).

Moreover, in the in vivo study, the therapeutic effect of NMPi at lower drug and light doses (drug dose of $2 \mathrm{mg} / \mathrm{kg}$ and total light dose of $200 \mathrm{~J} / \mathrm{cm}^{2}$ ) was comparable to that of the chlorin e6-loaded hyaluronic acid nanoparticles reported by Cai et al. $\left(660 \mathrm{~nm}\right.$ laser with $160 \mathrm{~mW} / \mathrm{cm}^{2}$ for $30 \mathrm{~min}$ (total light dose, $288 \mathrm{~J} / \mathrm{cm}^{2}$ ); drug dose, $5 \mathrm{mg} / \mathrm{kg}$; initial tumor size, $50-100 \mathrm{~mm}^{3}$ ) [32]. This result suggests that the treatment is effective against small-size tumors, while large-size tumors need higher drug and light doses to allow complete tumor eradication.

Tumor volume changes shown in Figure 7 clearly indicate that early treatment (small-size initial tumors) is important to obtain remarkable therapeutic effect [34-36]. Therefore, late treatment (large-size initial tumors) may be effective in PDT only with higher drug and light doses. NMPi for small-size initial tumors $\left(<50 \mathrm{~mm}^{3}\right)$ revealed excellent PDT activity with almost complete tumor eradication under the treatment condition.

The images for tumor surface alterations of A549 tumor-bearing mice (small- and large-tumor groups) after double intravenous injections (on Days 0 and 2, repeated two times PDT) of PBS, MPPa, and NMPi with $200 \mathrm{~J} / \mathrm{cm}^{2}$ light irradiation one day after each injection (on Days 1 and 3, repeated two times PDT) are shown in Figure 8. On the day of second PDT (on Day 3), mice in MPPa and NMPi groups showed hemorrhage where the light was delivered, and the tumor tissues were severely damaged due to the photogeneration of ROS followed by direct cellular damage and destruction of tumor tissue [3-7]. Mice in the small-tumor group $\left(<50 \mathrm{~mm}^{3}\right)$ treated with MPPa and NMPi under 
PDT had complete tumor eradication on Day 20. However, in large-tumor group $\left(>50 \mathrm{~mm}^{3}\right)$, tumor tissues were not completely eliminated.

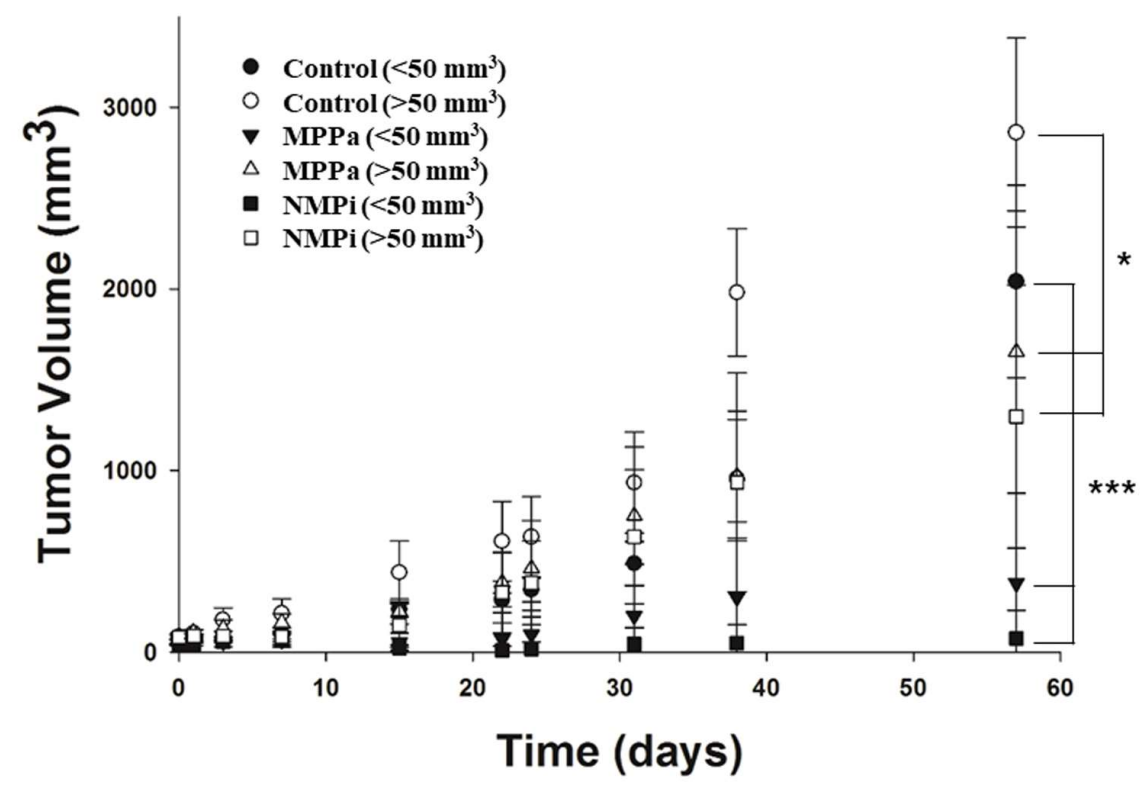

Figure 7. In vivo tumor volume changes in A549 tumor-bearing mice (small-tumor groups $<50 \mathrm{~mm}^{3}$, and large-tumor groups $>50 \mathrm{~mm}^{3}$ ) after double injections (on Days 0 and 2, repeated two times PDT) of PBS, MPPa (2 mg/kg), or NMPi (2 mg/ kg) followed by light irradiation $\left(200 \mathrm{~J} / \mathrm{cm}^{2}\right)$ one day after each injection (on Days 1 and 3, repeated two times PDT). Data are presented as means $\pm \operatorname{SD}(n=5)$. The tumor volume $\left(\mathrm{mm}^{3}\right)$ was calculated as (length $\times$ width $\left.{ }^{2}\right) / 2$. Therapeutic effect was higher in the order of $\mathrm{NMPi}\left(<50 \mathrm{~mm}^{3}\right)>\operatorname{MPPa}\left(<50 \mathrm{~mm}^{3}\right)>\mathrm{NMPi}\left(>50 \mathrm{~mm}^{3}\right)>\operatorname{MPPa}\left(>50 \mathrm{~mm}^{3}\right)$. ${ }^{* *} p<0.001$ and $* p<0.05$ (one-way ANOVA) indicate values that differ significantly from control (PBS) group in small-tumor groups $\left(<50 \mathrm{~mm}^{3}\right)$ and in large-tumor groups $\left(>50 \mathrm{~mm}^{3}\right)$, respectively.

In addition, the images of tumor surface alteration shown in Figure 8 indicate the reaction to light irradiation. On Day 4, one day after the second PDT, immediate reaction with damaged apoptotic tissues (dark color) in both small- and large-tumor groups was observed. The damaged tissues were healed on Day 20, 17 days after the second PDT, and small tumors treated with MPPa and NMPi completely disappeared; however, large tumors expressed regrowth.

PDT has a good advantage over other cancer treatments, in that it is a repeatable treatment. In this research, we also used repeatable PDT, such as two times of PDT on Day 1 and 3. We believe that repeatable PDT is important to allow complete tumor healing in the small-tumor groups. Wu et al. used repeated PDT for four times and reported high antibacterial efficacy [40]. Na et al. developed a repeatable endoscopic PDT-stent [41].

In this study, our in vivo results were better than our previous in vitro and in vivo results with use of the same drug $(2 \mathrm{mg} / \mathrm{kg})$ and light $\left(200 \mathrm{~J} / \mathrm{cm}^{2}\right.$ by $630 \mathrm{~nm}$ with $400 \mathrm{~mW} / \mathrm{cm}^{2}$ for $\left.500 \mathrm{~s}\right)$ doses using hematoporphyrin-modified doxorubicin-loaded nanoparticles [42] as well as hypocrellin B and paclitaxel loaded nanoparticles [43], not only because of the repeated two times PDT, but also because of the early treatment when the tumor size was small.

This result has a good agreement with previous clinical trials results. Five-year survival rate (\%) is highly affected by tumor sizes, such as $92.0 \%$ for $\leq 110 \mathrm{~cm}^{3}$ and $62.2 \%$ for $>110 \mathrm{~cm}^{3}$ [34]. William Jr. et al. have shown good relationship between tumor size and survival in non-small-cell lung cancer in their study after tumor sizes were categorized into four subgroups: $\leq 2 \mathrm{~cm}, 2-5 \mathrm{~cm}, 5-7 \mathrm{~cm}$, and $>7 \mathrm{~cm} \mathrm{[35].}$ Patients with a tumor size $\leq 2 \mathrm{~cm}$ have longer survival as reported by Rami-Porta et al. [36]. 
Hematoxylin and eosin (H\&E) staining images of tumor tissues in A549 tumor-bearing mice (small- and large-tumor groups) on Day 15, after double intravenous injection (on Days 0 and 2, repeated two times PDT) of PBS, MPPa, and NMPi with $200 \mathrm{~J} / \mathrm{cm}^{2}$ light irradiation on one day after each injection (on Days 1 and 3, repeated two times PDT) are shown in Figure 9.

The tumor cells were damaged in the same order as for the tumor size reduction in Figure 7. Mice in the small-tumor group treated with NMPi presented the most complete tumor cell eradication, which is also consistent with the result of tumor surface alterations in Figure 8. Furthermore, in Figure 10, we show the results of terminal deoxyribonucleotidyl transferse-mediated dUTP nick-end labelling (TUNEL) staining for detecting apoptotic DNA fragmentation in A549 tumor-bearing mice on Day 15. This result also had a good agreement with therapeutic effects observed in the H\&E staining images in Figure 9.

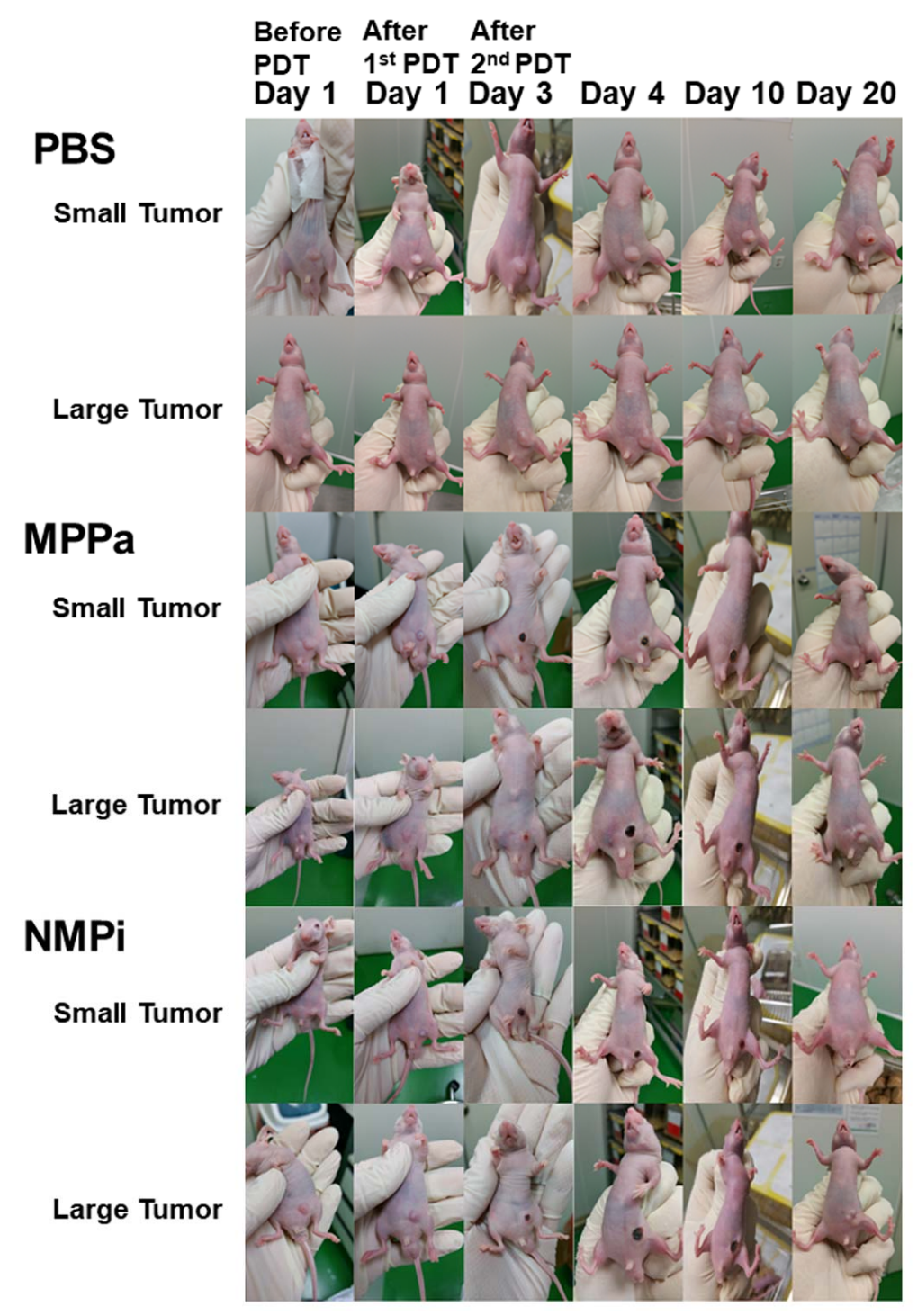

Figure 8. Tumor surface alterations of A549 tumor-bearing mice (small-tumor group $<50 \mathrm{~mm}^{3}$ and large-tumor group $>50 \mathrm{~mm}^{3}$ ) after double intravenous injection (on Days 0 and 2, repeated two times PDT) of PBS, MPPa (2 mg/kg), and NMPi $(2 \mathrm{mg} / \mathrm{kg})$ with $200 \mathrm{~J} / \mathrm{cm}^{2}$ light irradiation on one day after each injection (on Days 1 and 3, repeated two times PDT). Mice in the small-tumor group $\left(<50 \mathrm{~mm}^{3}\right)$ treated with MPPa and NMPi under PDT revealed complete tumor eradication on Day 20. However, in large-tumor group $\left(>50 \mathrm{~mm}^{3}\right)$, tumor tissues were not completely eliminated. 


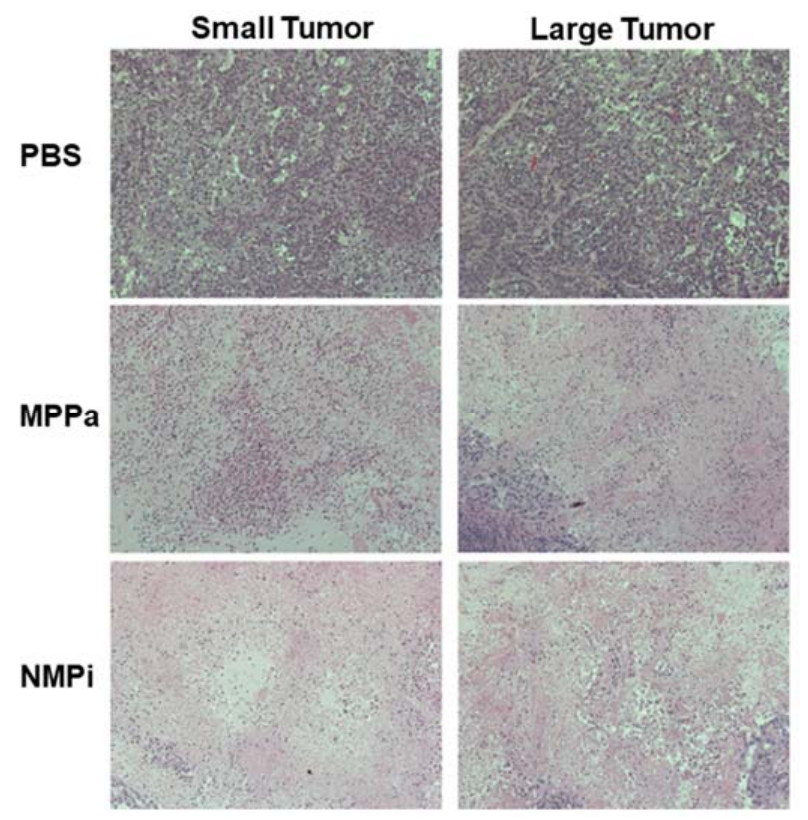

Figure 9. Hematoxylin and eosin (H\&E) staining of tumor tissues in A549 tumor-bearing mice (small-tumor group $<50 \mathrm{~mm}^{3}$ and large-tumor group $>50 \mathrm{~mm}^{3}$ ) on Day 15, after double intravenous injection (on Days 0 and 2, repeated two times PDT) of PBS, MPPa (2 mg/kg) and NMPi (2 mg/kg) with $200 \mathrm{~J} / \mathrm{cm}^{2}$ light irradiation on one day after each injection (on Days 1 and 3, repeated two times PDT). Mice in the small tumor group treated with NMPi presented the most complete tumor cell eradication, which was also consistent with the result of tumor surface alterations in Figure 8. The magnification is $40 \times$.

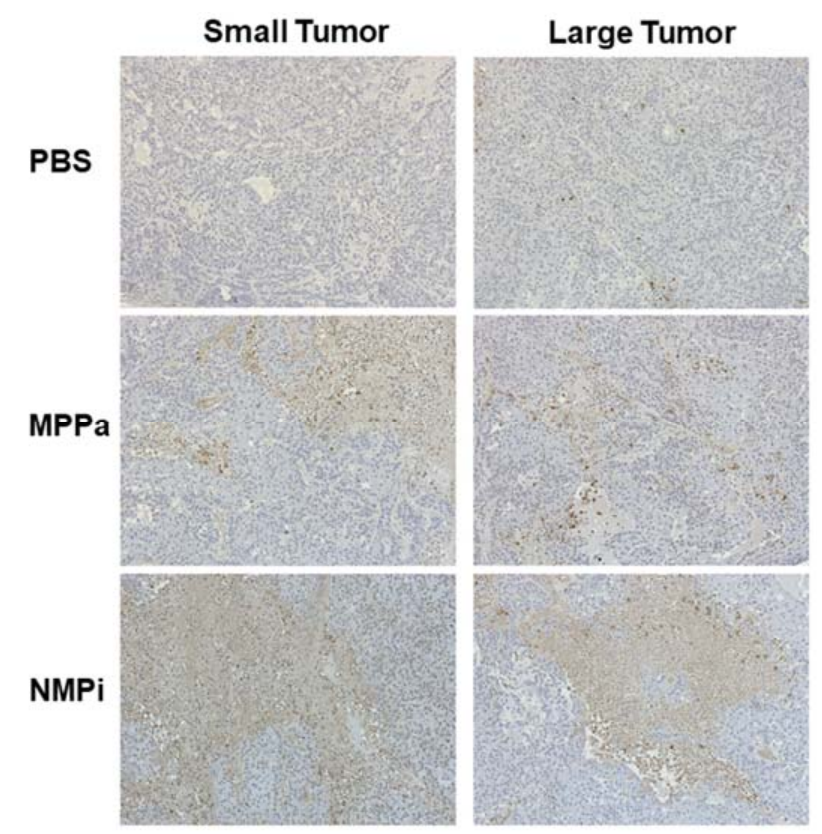

Figure 10. Terminal deoxyribonucleotidyl transferse-mediated dUTP nick-end labelling (TUNEL) staining of tumor tissues in A549 tumor-bearing mice (small-tumor group $<50 \mathrm{~mm}^{3}$ and large-tumor group $>50 \mathrm{~mm}^{3}$ ) on Day 15, after double intravenous injection (on Days 0 and 2, repeated two times PDT) of PBS, MPPa (2 mg/ kg), and NMPi $(2 \mathrm{mg} / \mathrm{kg})$ with $200 \mathrm{~J} / \mathrm{cm}^{2}$ light irradiation on one day after each injection (on Days 1 and 3, repeated two times PDT). This result also had a good agreement with therapeutic effects observed in the H\&E staining images in Figure 8. The magnification is $40 \times$. 
Consequently, under the PDT, small-tumor size groups have shown better photodynamic activity result than large-tumor size groups, and treatment with NMPi showed higher therapeutic effect than treated with MPPa.

\section{Materials and Methods}

\subsection{Materials}

RPMI-1640 medium, penicillin-streptomycin, and fetal bovine serum (FBS) were obtained from Gibco Life Technologies, Inc. (Grand Island, NY, USA). Phosphate buffered saline (PBS) was obtained from Sigma-Aldrich (St. Louis, MO, USA). 3-(4,5-Dimethylthiazol-2-yl)-2,5-diphenyltetrazolium bromide) MTT kit (EZ-CYTOX, DOGEN, Seoul, Korea), was obtained from DOGEN Bio.

\subsection{Synthesis of Photosensitizers}

Chlorophyll a-based photosensitizers, MPPa and NMPi, were synthesized according to a modified literature procedure by our group (Scheme 1) [21].

MPPa: Methyl pheophorbide a (MPa) was obtained from an extraction method of chlorophyll paste with $5 \%$ acidic methanol followed by column separation $\left(\mathrm{SiO}_{2}\right.$ and eluent $2 \%$ acetone $\left./ \mathrm{CH}_{2} \mathrm{Cl}_{2}\right)$. Then, MPa (500 mg) was dissolved in $100 \mathrm{~mL}$ 2,4,6-trimethylpyridine under stirring at reflux in a nitrogen environment. After 5 h, 2,4,6-trimethylpyridine was removed by evaporation under high vacuum, and the residue was purified by column separation $\left(\mathrm{SiO}_{2}\right.$ and eluent of $\left.2 \% \mathrm{MeOH} / \mathrm{CH}_{2} \mathrm{Cl}_{2}\right)$ to give a dark green solid (yield $85 \%$ ).

NMPi: Purpurin-18 methyl ester was obtained by reacting MPa with basic acetone in oxygen followed by column separation $\left(\mathrm{SiO}_{2}\right.$ and eluent $2 \%$ acetone $\left./ \mathrm{CH}_{2} \mathrm{Cl}_{2}\right)$. Purpurin-18 methyl ester (200 mg) was reacted with hydroxylamine hydrochloride (500 $\mathrm{mg}$, excess) in pyridine under stirring at room temperature for $5 \mathrm{~h}$. After that, the reaction solvent was removed by washing with aqueous $\mathrm{HCl}$ $(2 \mathrm{M}, 3 \times 100 \mathrm{~mL})$ and water $(3 \times 200 \mathrm{~mL})$. After removing all the solvent, the residue was dissolved in $\mathrm{CH}_{2} \mathrm{Cl}_{2}(10 \mathrm{~mL})$ and reacted with $5 \mathrm{~mL}$ diazomethane for $5 \mathrm{~min}$. The residue was purified by column separation $\left(\mathrm{SiO}_{2}\right.$ and eluent of $\left.3 \% \mathrm{MeOH} / \mathrm{CH}_{2} \mathrm{Cl}_{2}\right)$ to give a dark purple solid (yield $75 \%$ ).

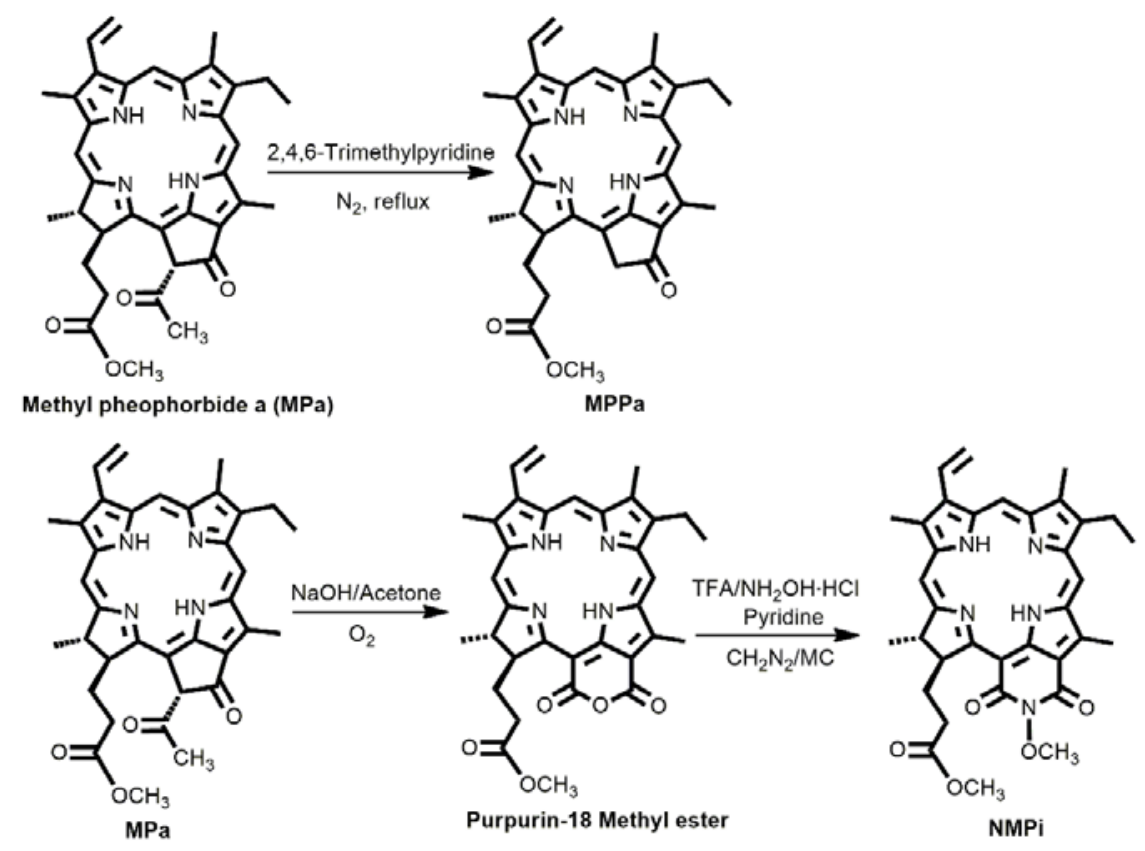

Scheme 1. Synthetic procedure of MPPa and NMPi. 


\subsection{In Vitro Phototoxicity}

\subsubsection{MTT Assay According to Concentration of Photosensitizer}

A549 cells were placed in a 96-well plate at $1 \times 10^{4}$ cells/well $(100 \mu \mathrm{L})$ to prepare an adherent culture. After $24 \mathrm{~h}$, the medium was removed, the cells were washed twice with PBS, and MPPa and $\mathrm{NMPi}$ at various concentrations $(0.1-20 \mu \mathrm{M}$ in $100 \mu \mathrm{L}$ of the medium) were added to each well. After $24 \mathrm{~h}$, the solutions were discarded, and the cells were washed thrice with PBS, followed by the addition of fresh medium $(100 \mu \mathrm{L} /$ well). The cells were then irradiated with a BioSpec LED (610-710 nm, $2 \mathrm{~J} / \mathrm{cm}^{2}$ ) from a distance of $20 \mathrm{~cm}$ for $15 \mathrm{~min}$, followed by an MTT assay to evaluate their response to PDT. In the assay, MTT solution $(10 \mu \mathrm{L})$ was added to each well followed by culturing in an incubator for $1 \mathrm{~h}$. Subsequently, the absorbance at $450 \mathrm{~nm}$ was measured with an ELISA-reader at 3 and $24 \mathrm{~h}$ after photoirradiation. All assays were performed in triplicate in three independent experiments.

\subsubsection{CCK-8 Assay According to Irradiation Time and Concentration of Photosensitizer}

A549 (human lung adenocarcinoma, ATCC, Manassas, VA, USA) cells were seeded in 24-well cell culture plates (Nunc, Roskilde, Denmark) at a density of $1 \times 10^{5}$ cells/well in RPMI-1640 medium containing $10 \%(v / v)$ FBS and $1 \%(w / v)$ penicillin-streptomycin and cultured for $24 \mathrm{~h}$ at $37^{\circ} \mathrm{C}$ with $5 \%$ $\mathrm{CO}_{2}$ and $95 \%$ air atmosphere in a humidified incubator. After $24 \mathrm{~h}$, the cells were washed with PBS and treated with PBS (control), or various concentrations $(1,5$, and $10 \mu \mathrm{M})$ of MPPa or NMPi. Both compounds were dissolved in DMSO $(1 \mathrm{mM}, 1 \mathrm{~mL})$ and were diluted with PBS, and then $1 \mathrm{~mL}$ of the solutions were added to each well. After $4 \mathrm{~h}$ of incubation, the cells were washed twice with PBS, and then fresh RPMI-1640 medium was added.

The tumor cell viability assay was performed using a Cell Counting Kit-8 (CCK-8) (Dojindo Molecular Technologies, Gaithersburg, MD, USA) [44]. The drug-treated cells were irradiated with a PDT laser (Diomed Inc., Andover, MA, USA) at $630 \mathrm{~nm}$ and $400 \mathrm{~mW} / \mathrm{cm}^{2}$ for various periods of time $\left(0,10,20,40\right.$, and $50 \mathrm{~s}$ corresponding to $0,4,8,16$, and $20 \mathrm{~J} / \mathrm{cm}^{2}$, respectively) and incubated for $24 \mathrm{~h}$ in the dark. The cells were washed twice with cold PBS and $10 \mu \mathrm{L}$ of CCK-8 solution and $100 \mu \mathrm{L}$ of culture medium were added to each well. Then, the cells were incubated in the dark for an additional $2 \mathrm{~h}$. The absorbance was read at a wavelength of $450 \mathrm{~nm}$ with a microplate reader (Spectramax plus 384, Molecular Devices Corporation, Sunnyvale, CA, USA). All assays were performed in triplicate in three independent experiments.

\subsection{Microscopic Analysis}

The cells were irradiated with a PDT laser $\left(630 \mathrm{~nm}, 400 \mathrm{~mW} / \mathrm{cm}^{2}\right)$ for 0 and $20 \mathrm{~s}(0$ and $8 \mathrm{~J} / \mathrm{cm}^{2}$, respectively), incubated in the dark for $24 \mathrm{~h}$, and washed twice with cold PBS. The annexin V-FITC fluorescence microscopy kit (BD bioscience, San Jose, CA, USA) was used to identify apoptotic cells [45]. The cells were stained with both annexin V-FITC and DAPI (Vector Laboratories, Burlingame, CA, USA), and the apoptotic cells were counted on the fluorescence microscope (Axioskop 40, Carl Zeiss, Göttingen, Germany).

\subsection{Singlet Oxygen Photogeneration Study}

DPBF study was carried out to evaluate relative photogeneration of singlet oxygen $\left({ }^{1} \mathrm{O}_{2}\right)$ after photoirradiation (total light dose $2 \mathrm{~J} / \mathrm{cm}^{2}$ ) [46]. After DPBF bind with ${ }^{1} \mathrm{O}_{2}$, the furan ring on DPBF opens up to generate a diketone, resulting in the decay of absorbance of DPBF at $418 \mathrm{~nm}$. DPBF was used as a selective ${ }^{1} \mathrm{O}_{2}$ acceptor, being bleached upon reaction with ${ }^{1} \mathrm{O}_{2}$. Four sample solutions of DPBF in DMSO $(50 \mu \mathrm{M})$ containing DPBF only (50 $\mu \mathrm{M}$, control sample), DPBF + methylene blue (MB) $(1 \mu \mathrm{M}), \mathrm{DPBF}+\mathrm{MPPa}(1 \mu \mathrm{M})$, and DPBF + NMPi $(1 \mu \mathrm{M})$ were prepared in the dark. All samples were placed in a 96-well plate and covered with aluminum foil. The samples were irradiated $\left(2 \mathrm{~J} / \mathrm{cm}^{2}\right)$ for $15 \mathrm{~min}$. After irradiation, visible spectra of the sample solutions were recorded, and the normalized absorbances of DPBF at $418 \mathrm{~nm}$ were reported (Figure 11). The ${ }^{1} \mathrm{O}_{2}$ photogeneration activities of MPPa 
and NMPi were compared based on the different absorbance decay profiles of each sample relative to that of the DPBF control sample.

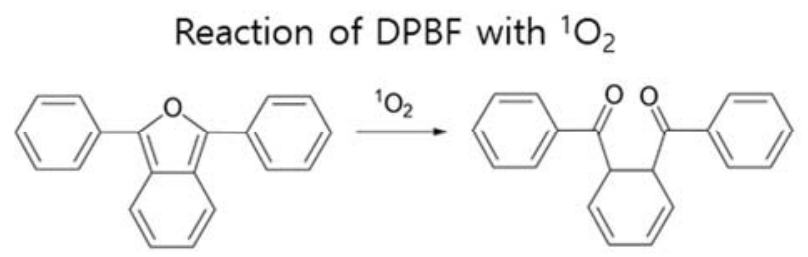

Figure 11. Reaction of DPBF with ${ }^{1} \mathrm{O}_{2}$ to decrease its absorbance at $418 \mathrm{~nm}$, which depends on the amount of ${ }^{1} \mathrm{O}_{2}$ photogeneration.

\subsection{FACS Analysis}

The cells were irradiated with a PDT laser $\left(630 \mathrm{~nm}, 400 \mathrm{~mW} / \mathrm{cm}^{2}\right)$ for $0,10,20,40$, and $50 \mathrm{~s}$ $\left(0,4,8,16\right.$, and $20 \mathrm{~J} / \mathrm{cm}^{2}$, respectively). The irradiated cells were incubated in the dark for $24 \mathrm{~h}$ and washed twice with cold PBS. The cells were stained with both annexin V-FITC and PI (BD Biosciences, San Jose, CA, USA) [47]. The stained cells were resuspended in $1 \mathrm{~mL}$ of $1 \times$ binding buffer and then $100 \mu \mathrm{L}$ of the sample solution was transferred to a $5 \mathrm{~mL}$ round-bottom tube. Annexin V-FITC $(5 \mu \mathrm{L})$ and PI $(5 \mu \mathrm{L})$ were added into the sample solution and incubated in the dark for $15 \mathrm{~min}$ at room temperature. Finally, binding buffer $(400 \mu \mathrm{L})$ was added and the apoptotic cells were detected by flow cytometry (FACSCalibur, BD Biosciences) using CellQuest software (BD Immunocytometry Systems, Mountain View, CA, USA). The excitation wavelengths of PI and annexin V-FITC were $488 \mathrm{~nm}$ and $635 \mathrm{~nm}$, respectively. The emission wavelengths of PI and annexin V-FITC were $610 \pm 20 \mathrm{~nm}$ and $660 \pm 20 \mathrm{~nm}$, respectively. Acquired cells on the flow cytometer were collected per 10,000 events.

\subsection{Animals and Tumor Model}

BALB/c male nude mice (6-7 weeks, 20-22 g) were purchased from Orientbio (Gyeonggi-do, Korea). All animal study protocols were approved by the Institutional Animal Care and Use Committee of Seoul National University Bundang Hospital on 20 December 2016 (BA1612-214/081-01). A549 cells at $1 \times 10^{6}$ in $0.1 \mathrm{~mL}$ RPMI-1640 medium were injected into the left flanks of all mice subcutaneously at the same time [32]. During treatment, mice were anesthetized with $\mathrm{CO}_{2}$ at a flow rate of $0.1 \mathrm{~L} / \mathrm{min}$. The tumor size of each mouse was measured by a caliper for 57 days to investigate PDT efficacy. The tumor sizes $\left(\mathrm{mm}^{3}\right)$ were calculated as the volume (tumor length) $\times(\text { tumor width })^{2} / 2$ [48]. Tumor volumes of A549 tumor-bearing mice reached $<50 \mathrm{~mm}^{3}$ (small-size) and $>50 \mathrm{~mm}^{3}$ (large-size) after seven and ten days, respectively.

\subsection{In Vivo Anticancer Efficacy in Tumor-Bearing Mice}

In vivo anticancer efficacy was performed using A549 tumor-bearing mice. The mice were divided into two groups according to the tumor size; a small-tumor group $\left(<50 \mathrm{~mm}^{3}\right)$ and a large-tumor group $\left(>50 \mathrm{~mm}^{3}\right)$. Then, the two groups were classified into three subgroups: control, MPPa and NMPi $(n=5$ each). The mice were injected twice (on Days 0 and 2, repeated PDT) with PBS, MPPa ( $2 \mathrm{mg} / \mathrm{kg}$ ), or NMPi $(2 \mathrm{mg} / \mathrm{kg})$ via the tail vein. Twenty-four hours after each injection, tumors were irradiated by a PDT laser $\left(630 \mathrm{~nm}\right.$ with $400 \mathrm{~mW} / \mathrm{cm}^{2}$ ) for $500 \mathrm{~s}$ (total light dose of $200 \mathrm{~J} / \mathrm{cm}^{2}$ ) twice (on Days 1 and 3, repeated PDT). The surface changes at the tumor site were also monitored.

\subsection{Histology Examination}

For histology analysis, the mice (one mouse in each group) were sacrificed on Day 15, and the tumor tissues of mice in each subgroup from the small- and large-tumor groups were excised, fixed in $10 \%$ formalin, and then embedded in paraffin. Tissue sections were deparaffinized in xylene, 
dehydrated in graded alcohols, and washed in distilled water. The tissues were sectioned into 5 - $\mu \mathrm{m}$-thick slices for H\&E staining.

\subsection{TUNEL Assay for Apoptosis}

For TUNEL assay, the mice (one mouse in each group) were sacrificed on Day 15, and the tumor tissues of mice in each subgroup from the small- and large-tumor groups were excised. Apoptotic cell death in paraffin-embedded tumor tissue sections was detected using the in situ Cell Death Detencion Kit according to the manufacturer's method.

\subsection{Statistical Analysis}

All data are presented as means \pm standard deviation (SD). The statistical significance among the three groups (control, MPPa and NMPi) was determined by one-way analysis of variance (ANOVA) and multiple comparisons (Fisher's method as a post-hoc test) with the Statistical Program for Social Sciences software (SPSS). In all analyses, $p<0.05$ was considered statistically significant difference.

\section{Conclusions}

In this study, we demonstrated that the two chlorin derivatives as second-generation photosensitizers, MPPa and NMPi, show high anticancer efficacy by PDT against A549 human lung adenocarcinoma cells in vitro as well as in A549 tumor-bearing mice in vivo. Tumor cell viability was evaluated by both MTT and CCK-8 assays, and we found that PDT activity significantly depends on the irradiation time and the concentration of the photosensitizer. MPPa showed better phototoxicity than NMPi. For the in vivo study, we used two times repeatable PDT method and compared the results between the small-size $\left(\leq 50 \mathrm{~mm}^{3}\right)$ and the large-size $\left(>50 \mathrm{~mm}^{3}\right)$ tumor groups. As expected, mice in the small-tumor groups healed better than those in the large-tumor groups.

Importantly, in our in vivo system, both MPPa and NMPi decreased tumor growth than the control. More importantly, NMPi has shown excellent tumor eradication not only because of the repeatable two times PDT as an advantage of PDT compared with other anticancer treatments, but also because of the small-size of tumor correlating with early cancer treatment.

To the best of our knowledge, this study is the first paper to show relative anticancer results by PDT corresponding to the different tumor sizes. Therefore, these results could be useful to develop new potential photosensitizers for PDT as well as for understanding the relationship between tumor size and anticancer efficacy.

Supplementary Materials: The following are available online at http:/ /www.mdpi.com/1422-0067/19/6/1596/ s1.

Author Contributions: J.-E.C. and Y.L. contributed equally for the experiments contain synthesis of the chlorin derivatives, and in vitro and in vivo studies. T.H.L. contributed to the in vitro study. W.K.L. gave financial support and suggestions. I.Y and K.K. are corresponding authors and contributed with financial support and in preparation of the paper.

Acknowledgments: This study was supported by the SNUBH Research Fund (14-2015-004), Research Resettlement Fund for the new faculty of Seoul National University (35-2015-0083), and National Research Foundation (NRF) of Korea grant funded by the Korea government (NRF-2015R1D1A1A01057746 and NRF-2017R1A2B4010615).

Conflicts of Interest: The authors declare no conflict of interest.

\section{References}

1. The Cancer Genome Atlas Research Network. Comprehensive molecular profiling of lung adenocarcinoma. Nature 2014, 511, 543-550.

2. Sharouni, S.Y.E.; Kal, H.B.; Battermann, J.J. Accelerated regrowth of non-small-cell lung tumours after induction chemotherapy. Br. J. Cancer 2003, 89, 2184-2189. [CrossRef] [PubMed] 
3. Kostron, H.; Hasan, T. (Eds.) Photodynamic Medicine: From Bench to Clinic; Royal Society of Chemistry: Cambridge, UK, 2016.

4. Pandey, R.K.; Kessel, D.; Dougherty, T.J. (Eds.) Handbook of Photodynamic Therapy: Updates on Recent Applications of Porphyrin-Based Compounds; World Scientific Publishing: Singapore, 2016.

5. Dolmans, D.E.; Fukumura, D.; Jain, R.K. Photodynamic therapy for cancer. Nat. Rev. Cancer 2003, 3, $380-387$. [CrossRef] [PubMed]

6. Dougherty, T.J.; Marcus, S.L. Photodynamic therapy. Eur. J. Cancer 1992, 28a, 1734-1742. [CrossRef]

7. Pass, H.I. Photodynamic therapy in oncology: Mechanisms and clinical use. J. Natl. Cancer Inst. 1993, 85, 443-456. [CrossRef] [PubMed]

8. Folkes, L.K.; Wardman, P. Enhancing the efficacy of photodynamic cancer therapy by radicals from plant auxin (indole-3-acetic acid). Cancer Res. 2003, 63, 776-779. [PubMed]

9. Ackroyd, R.; Kelty, C.; Brown, N.; Reed, M. The history of photodetection and photodynamic therapy. Photochem. Photobiol. 2001, 74, 656-669. [CrossRef]

10. Moghissi, K.; Dixon, K.; Thorpe, J.A.C.; Stringer, M.; Oxtoby, C. Photodynamic therapy (PDT) in early central lung cancer: A treatment option for patients ineligible for surgical resection. Thorax 2007, 62, 391-395. [CrossRef] [PubMed]

11. Tang, C.-Y.; Wu, F.-Y.; Yang, M.-K.; Guo, Y.-M.; Lu, G.-H.; Yang, Y.-H. A classic near-infrared probe indocyanine green for detecting singlet oxygen. Int. J. Mol. Sci. 2016, 17, 219. [CrossRef] [PubMed]

12. Bazylińska, U.; Frąckowiak, R.; Brzózka, Z.; Wilk, K.A. The effect of anionic dicephalic surfactants on fabrication of varied-core nanocarriers for sustained release of porphyrin photosensitizers. J. Photochem. Photobiol. B Biol. 2017, 166, 169-179. [CrossRef] [PubMed]

13. Henderson, B.W.; Bellnier, D.A.; Greco, W.R.; Sharma, A.; Pandey, R.K.; Vaughan, L.A.; Weishaupt, K.R.; Dougherty, T.J. An in vivo quantitative structure-activity relationship for a congeneric series of pyropheophorbide derivatives as photosensitizers for photodynamic therapy. Cancer Res. 1997, 57, 4000-4007. [PubMed]

14. Lobel, J.; MacDonald, I.J.; Ciesielski, M.J.; Barone, T.; Potter, W.R.; Pollina, J.; Plunkett, R.J.; Fenstermaker, R.A.; Dougherty, T.J. 2-[1-Hexyloxyethyl]-2-devinyl pyropheophorbide-a (HPPH) in a nude rat glioma model: Implications for photodynamic therapy. Lasers Surg. Med. 2001, 29, 397-405. [CrossRef] [PubMed]

15. Usuda, J.; Ichinose, S.; Ishizumi, T.; Hayashi, H.; Ohtani, K.; Maehara, S.; Ono, S.; Honda, H.; Kajiwara, N.; Uchida, O.; et al. Outcome of photodynamic therapy using NPe6 for bronchogenic carcinomas in central airways $>1.0 \mathrm{~cm}$ in diameter. Clin. Cancer Res. 2010, 16, 2198-2204. [CrossRef] [PubMed]

16. Spikes, J.D. New trends in photobiology: Chlorins as photosensitizers in biology and medicine. J. Photochem. Photobiol. B Biol. 1190, 6, 259-274. [CrossRef]

17. Smith, K.M.; Goff, D.A.; Simpson, D.J. The meso substitution of chlorophyll derivatives: Direct route for transformation of bacteriopheophorbides d into bacteriopheophorbides c. J. Am. Chem. Soc. 1985, 107, 4946-4954. [CrossRef]

18. Li, J.; Zhang, X.; Liu, Y.; Yoon, I.; Kim, D.-K.; Yin, J.-G.; Wang, J.-J.; Shim, Y.K. Synthesis, optical properties and preliminary in vitro photodynamic effect of pyridyl and quinoxalyl substituted chlorins. Bioorg. Med. Chem. 2015, 23, 1684-1690. [CrossRef] [PubMed]

19. Cui, B.C.; Yoon, I.; Li, J.; Lee, W.K.; Shim, Y.K. Synthesis and characterization of novel purpurinimides as photosensitizers for photodynamic therapy. Int. J. Mol. Sci. 2014, 15, 8091-8105. [CrossRef] [PubMed]

20. Cui, B.C.; Yoon, I.; Li, J.Z.; Shim, Y.K. Novel cationic purpurinimides as potential photosensitizers: Design, synthesis and biological evaluation. J. Chem. Pharm. Res. 2013, 5, 818-823.

21. Li, J.Z.; Wang, J.J.; Yoon, I.; Cui, B.C.; Shim, Y.K. Synthesis of novel long wavelength cationic chlorins via stereoselective aldol-like condensation. Bioorg. Med. Chem. Lett. 2012, 22, 1846-1849. [CrossRef] [PubMed]

22. Yoon, I.; Park, H.S.; Cui, B.C.; Kim, J.H.; Shim, Y.K. Synthesis and photodynamic activities of pyrazolyl and cyclopropyl derivatives of purpurin-18 methyl ester and purpurin-18-N-butylimide. Bull. Korean Chem. Soc. 2011, 32, 169-174. [CrossRef]

23. Cui, B.C.; Cha, M.U.; Li, J.Z.; Park, H.S.; Yoon, I.; Shim, Y.K. Efficient synthesis and in vitro PDT effect of purpurin-18-N-aminoimides. Bull. Korean Chem. Soc. 2010, 31, 3313-3317. [CrossRef]

24. Sun, B.; Li, W.; Liu, N. Curative effect of the recent photofrin photodynamic adjuvant treatment on young patients with advanced colorectal cancer. Oncol. Lett. 2016, 11, 2071-2074. [CrossRef] [PubMed] 
25. Ikeda, H.; Tobita, T.; Ohba, S.; Uehara, M.; Asahina, I. Treatment outcome of photofrin-based photodynamic therapy for T1 and T2 oral squamous cell carcinoma and dysplasia. Photodiagn. Photodyn. Ther. 2013, 10, 229-235. [CrossRef] [PubMed]

26. Van Straten, D.; Mashayekhi, V.; de Bruijn, H.S.; Oliveira, S.; Robinson, D.J. Oncologic photodynamic therapy: Basic principles, current clinical status and future directions. Cancers 2017, 9, 19. [CrossRef] [PubMed]

27. Banerjee, S.M.; MacRobert, A.J.; Mosse, C.A.; Periera, B.; Bown, S.G.; Keshtgar, M.R.S. Photodynamic therapy: Inception to application in breast cancer. Breast 2017, 31, 105-113. [CrossRef] [PubMed]

28. Meng, X.; Yang, Y.; Zhou, L.; Zhang, L.; Lv, Y.; Li, S.; Wu, Y.; Zheng, M.; Li, W.; Gao, G.; et al. Dual-responsive molecular probe for tumor targeted imaging and photodynamic therapy. Theranostics 2017, 7, 1781-1794. [CrossRef] [PubMed]

29. Bazylińska, U.; Saczko, J. Nanoemulsion-templated polyelectrolyte multifunctional nanocapsules for DNA entrapment and bioimaging. Colloids Surf. B Biointerfaces 2016, 137, 191-202. [CrossRef] [PubMed]

30. Bazylińska, U.; Saczko, J.; Zielińska, K.; Wilk, K.A. Novel multilayer IR-786-loaded nanocarriers for intracellular delivering: Characterization, imaging, and internalization in human cancer cell lines. Chem. Lett. 2012, 41, 1354-1356. [CrossRef]

31. Ding, Y.-F.; Li, S.; Liang, L.; Huang, Q.; Yuwen, L.; Yang, W.; Wang, R.; Wang, L.-H. Highly biocompatible chlorin e6-loaded chitosan nanoparticles for improved photodynamic cancer therapy. ACS Appl. Mater. Interfaces 2018, 10, 9980-9987. [CrossRef] [PubMed]

32. Li, W.; Zheng, C.; Pan, Z.; Chen, C.; Hu, D.; Gao, G.; Kang, S.; Cui, H.; Gong, P.; Cai, L. Smart hyaluronidase-actived theranostic micelles for dual-modal imaging guided photodynamic therapy. Biomaterials 2016, 101, 10-19. [CrossRef] [PubMed]

33. Furukawa, K.; Kato, H.; Konaka, C.; Okunaka, T.; Ususa, J.; Ebihara, Y. Locally recurrent central-type early stage lung cancer $<1.0 \mathrm{~cm}$ in diameter after complete remission by photodynamic therapy. Chest 2005, 128, 3269-3275.

34. Seçil, M.; Çullu, N.; Aslan, G.; Mungan, U.; Uysal, F.; Tuna, B.; Yörükoğlu, K. The effect of tumor volume on survival in patients with renal cell carcinoma. Diagn. Interv. Radiol. 2012, 18, 480-487. [PubMed]

35. Zhang, J.; Gold, K.A.; Lin, H.Y.; Swisher, S.G.; Xing, Y.; Lee, J.J.; Kim, E.S.; William, W.N., Jr. Relationship between tumor size and survival in non-small-cell lung cancer (NSCLC). An analysis of the surveillance, epidemiology, and end results (SEER) registry. J. Thorac. Oncol. 2015, 10, 682-690. [CrossRef] [PubMed]

36. Ball, D.; Mitchell, A.; Giroux, D.; Rami-Porta, R. Effect of tumor size on prognosis in patients treated with radical radiotherapy or chemoradiotherapy for non-small-cell lung cancer. An analysis of the staging project database of the international association for the study of lung cancer. J. Thorac. Oncol. 2013, 8, 315-321. [CrossRef] [PubMed]

37. Filonenko, E.V.; Sokolov, V.V.; Chissov, V.I.; Lukyanets, E.A.; Vorozhtsov, G.N. Photodynamic therapy of early esophageal cancer. Photodiagn. Photodyn. Ther. 2008, 5, 187-190. [CrossRef] [PubMed]

38. Usuda, J.; Kato, H.; Okunaka, T.; Furukawa, K.; Tsutsui, H.; Yamada, K.; Suga, Y.; Honda, H.; Nagatsuka, Y.; Ohira, T. Photodynamic therapy (PDT) for lung cancers. J. Thorac. Oncol. 2006, 1, 489-493. [CrossRef]

39. Kofler, B.; Romani, A.; Pritz, C.; Steinbichler, T.B.; Schartinger, V.H.; Riechelmann, H.; Dudas, J. Photodynamic effect of methylene blue and low level laser radiation in head and neck squamous cell carcinoma cell lines. Int. J. Mol. Sci. 2018, 19, 1107. [CrossRef] [PubMed]

40. Mao, C.; Xiang, Y.; Liu, X.; Cui, Z.; Yang, X.; Li, Z.; Zhu, S.; Zheng, Y.; Yeung, K.W.K.; Wu, S. Repeatable photodynamic therapy with triggered signaling pathways of fibroblast cell proliferation and differentiation to promote bacteria-accompanied wound healing. ACS Nano 2018, 12, 1747-1759. [CrossRef] [PubMed]

41. Bae, B.-C.; Yang, S.-G.; Jeong, S.; Lee, D.H.; Na, K.; Kim, J.M.; Costamagna, G.; Kozarek, R.A.; Isayama, H.; Deviere, J.; et al. Polymeric photosensitizer-embedded self-expanding metal stent for repeatable endoscopic photodynamic therapy of cholangiocarcinoma. Biomaterials 2014, 35, 8487-8495. [CrossRef] [PubMed]

42. Chang, J.-E.; Yoon, I.-S.; Sun, P.-L.; Yi, E.; Jheon, S.; Shim, C.K. Anticancer efficacy of photodynamic therapy with hematoporphyrin-modified, doxorubicin-loaded nanoparticles in liver cancer. J. Photochem. Photobiol. B Biol. 2014, 140, 49-56. [CrossRef] [PubMed]

43. Chang, J.-E.; Cho, H.-J.; Yi, E.; Kim, D.D.; Jheon, S. Hypocrellin B and and paclitaxel-encapsulated hyaluronic acid-ceramide nanoparticles for targeted photodynamic therapy in lung cancer. J. Photochem. Photobiol. B Biol. 2016, 158, 113-121. [CrossRef] [PubMed] 
44. Gao, X.; Chen, T.; Xing, D.; Wang, F.; Pei, Y.; Wei, X. Single cell analysis of PKC activation during proliferation and apoptosis induced by laser irradiation. J. Cell. Physiol. 2006, 206, 441-448. [CrossRef] [PubMed]

45. Lee, S.J.; Koo, H.; Jeong, H.; Huh, M.S.; Choi, Y.; Jeong, S.Y.; Byun, Y.; Choi, K.; Kim, K.; Kwon, I.C. Comparative study of photosensitizer loaded and conjugated glycol chitosan nanoparticles for cancer therapy. J. Control. Release 2011, 152, 21-29. [CrossRef] [PubMed]

46. Tian, J.; Xu, L.; Xue, Y.; Jiang, X.; Zhang, W. Enhancing photochemical internalization of DOX through a porphyrin-based amphiphilic block copolymer. Biomacromolecules 2017, 18, 3992-4001. [CrossRef] [PubMed]

47. Chen, S.; Cheng, A.-C.; Wang, M.-S.; Peng, X. Detection of apoptosis induced by new type gosling viral enteritis virus in vitro through fluorescein annexin V-FITC/PI double labeling. World J. Gastroenterol. 2008, 14, 2174-2178. [CrossRef] [PubMed]

48. Tomayko, M.M.; Reynolds, C.P. Determination of subcutaneous tumor size in athymic (nude) mice. Cancer Chemother. Pharmacol. 1989, 24, 148-154. [CrossRef] [PubMed]

(C) 2018 by the authors. Licensee MDPI, Basel, Switzerland. This article is an open access article distributed under the terms and conditions of the Creative Commons Attribution (CC BY) license (http://creativecommons.org/licenses/by/4.0/). 